\title{
Declining catch rates of small scale fishers in the southern North Sea in relation to the pulse transition in the beam trawl fleet
}

Author(s): $\quad$ Adriaan D. Rijnsdorp, Jacco van Rijssel, Niels Hintzen.

Publication date: July 2018

This research project was carried out by Wageningen Marine Research at the request of and with funding from the Ministry of Economic Affairs for the purposes of Policy Support Research Theme

'Nature inclusive fisheries' (BAS code BO-43-023.02-007-WMR).

Wageningen Marine Research

IJmuiden, July 2018

CONFIDENTIAL no

Wageningen Marine Research report C051/18 
Adriaan D. Rijnsdorp, Jacco van Rijssel, Niels Hintzen. Declining catch rates of small scale fishers in the southern North Sea in relation to the pulse transition in the beam trawl fleet. Wageningen, Wageningen Marine Research (University \& Research centre), Wageningen Marine Research report C051/18. 26 pp.

.

Keywords: Pulse fisheries, Small scale fishers, Gillnetters, Hand-liners, Sole, Cod, Seabass, Competition.

Client: $\quad$ Ministerie LNV

Attn.: Mevr E. Ranshuysen

Directie ELVV

Den Haag

BAS code BO-43-023.02-007-WMR

This report can be downloaded for free from https://doi.org/10.18174/455956

Wageningen Marine Research provides no printed copies of reports

Wageningen Marine Research is ISO 9001:2008 certified.

(C) 2016 Wageningen Marine Research Wageningen UR

Wageningen Marine Research The Management of Wageningen Marine Research is not responsible for resulting institute of Stichting Wageningen damage, as well as for damage resulting from the application of results or Research is registered in the Dutch research obtained by Wageningen Marine Research, its clients or any claims traderecord nr. 09098104, related to the application of information found within its research. This report BTW nr. NL 806511618 has been made on the request of the client and is wholly the client's property. This report may not be reproduced and/or published partially or in its entirety without the express written consent of the client. 


\section{Contents}

$\begin{array}{lr}\text { Abstract } & 4\end{array}$

1 Introduction $\quad 5$

$2 \quad$ Materials and Methods $\quad 6$

2.1 Catch and effort data 6

2.2 Analysis 6

2.2.1 Catch rate $\quad 6$

$\begin{array}{ll}2.2 .2 \text { VMS } & 7\end{array}$

$\begin{array}{llr}3 & \text { Results } & 8\end{array}$

3.1 Testimonies $\quad 8$

3.2 Effort and landings $\quad 8$

3.3 Effort and landings today's pulse license holders 9

3.4 Changes in effort and landings in the southern North Sea 10

3.5 Changes in catch rate in the southern North Sea 11

$\begin{array}{lll}3.5 .1 \text { Sole } & 11\end{array}$

$\begin{array}{ll}3.5 .2 \text { Cod } & 12\end{array}$

$\begin{array}{lll}3.5 .3 & \text { Seabass } & 13\end{array}$

$\begin{array}{lll}3.5 .4 & \text { All fish } & 13\end{array}$

3.6 Catch efficiency of pulse trawl and beam trawl

4 Discussion $\quad 16$

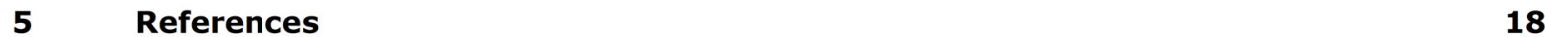

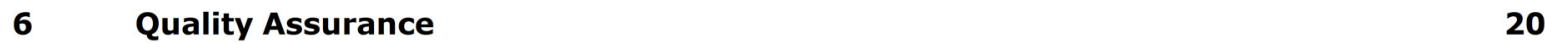

$\begin{array}{lr}\text { Justification } & 21\end{array}$

$\begin{array}{llr}7 & \text { Appendices } & 22\end{array}$

Appendix 1. Fishing effort (hours) of the pulse license holders fishing with the traditional beam trawl (TBB_SOL) or with the pulse trawl (PUL_SOL) by ICES rectangle in the southern North Sea. The total effort gives the annual effort in the North Sea.

Appendix 2. Landings of sole $\left(10^{3} \mathrm{~kg}\right)$ of the Dutch pulse license holders fishing with the traditional beam trawl (TBB_SOL) or with the pulse trawl (PUL_SOL) by ICES rectangles in the southern North Sea 


\section{Abstract}

This report analyses the complaints of gillnet and handline fishers working in the coastal waters of Belgium and the Netherlands about declining catches which they relate to the arrival of pulse trawlers. The testimonies are compared to (i) trends in the catch rate of sole, cod and seabass estimated for the beam trawl fisheries in six different areas of the southern North Sea and (ii) trends in the spawning stock biomass of these species estimated by ICES. It is shown that the catch rate of sole in the beam trawl fishery increased between 2009 and 2016. Therefore it is unlikely that the decline in the catch of sole in gillnets is due to a decline in the biomass of sole in the southern North Sea. It is more likely that the decline is due to the competition with pulse trawlers which are more efficient in catching sole than traditional beam trawlers. The decline in cod catches in gillnet and handline fisheries matched the declining catch rate of beam trawlers between spring and autumn suggesting that the decline is related to a decline in stock size in the southern North Sea. For seabass the decline in catch rates of the small scale fishers is likely related to the decrease in stock size. 


\section{Introduction}

The transition in Dutch fleet fishing for sole $(80 \mathrm{~mm}$ codend mesh) underwent a transition from using tickler chain beam trawls or Sumwing to using Pulsewing or Delmeco pulse beam trawl. At present 78 Dutch and 11 flag vessels are fishing with the pulse for sole (ICES, 2018). During the transition, the distribution pattern of pulse trawlers shifted to the southern North Sea (Turenhout et al., 2016). Anecdotal information from the fisheries indicate that pulse trawlers are able to deploy their gear on softer grounds than when fishing with the traditional beam trawl. The increase in pulse trawling in the southern North Sea gave rise to complaints from other fishers, such as gill netters and hand-liners, about possible adverse effects. A report summarises the complaints of a number of small scale fishers voiced at a meeting on 1 September 2017 (Anon, 2017). There was a general consensus among small scale fishers on declining catches in recent years coinciding with the increase in pulse trawl activities in the area. In a meeting in March 2018 in IJmuiden similar concerns were expressed (Steijns et al., 2018).

In this report, changes in fishing effort and corresponding landings of sole, cod and seabass are analysed in the southern North Sea.

The objective of this study is to

- analyse the complaints made in the light of the species, areas and gear groups involved,

- $\quad$ analyse the time trend in the removal of fish species by the pulse trawl fleet

- map the changes in fishing effort distribution of the beam trawl fleet and the pulse trawl fleet

- discuss the possible effects of the recent increase in pulse trawling on the catch rate of small scale fishers 


\section{Materials and Methods}

\subsection{Catch and effort data}

Catch and effort data by fishing trip (landings by species, hours at sea, rectangle, gear, mesh size, vessel ID, landing date) were extracted from the VISSTAT data base for the vessels that have obtained a pulse license to fish for sole. These vessels represents today's pulse license holders that have switched from the traditional beam trawl with tickler chains (beam trawl or sumwing) to the pulse trawl (pulswing or delmeco pulse trawl).

Because the VISSTAT data base does not distinguish between the tickler chain and pulse trawl, fishing trips were assigned to the pulse trawl based on the reported mesh size $(70-99 \mathrm{~mm})$ in combination with the estimated towing speed during fishing (VMS recordings) and the start date of the pulse license reported in the vessel register (data LNV).

Vessels may be engaged in different fisheries (metiers). The large vessels with an engine power exceeding $221 \mathrm{~kW}$ target sole with the traditional beam trawl (TBB_SOL) or a pulse trawl (PUL_SOL) using a mesh size of $80 \mathrm{~mm}$ (reported mesh size $70-99 \mathrm{~mm}$ ), or target plaice using a mesh size of at least $100 \mathrm{~mm}$ (TBB_PLE). The smaller vessels (Euro cutters) with an engine power of $<=221 \mathrm{~kW}$, can be engaged in the above metiers and in addition target brown shrimps (TBB_CRG) using a small mesh size, or fish for nephrops or demersal fish with an otter (twin) trawl. Trips in which vessels have landed brown shrimps were assigned as shrimp fishing.

For the small scale fishers, catch and effort data were extracted for the static gears (codes) and hand lines (codes) and for the species sole, cod and seabass. Recreational fisheries are not included in this report.

\section{$2.2 \quad$ Analysis}

\subsubsection{Catch rate}

If catching opportunities for the small scale fisheries indeed declined, we expect to find a decline in catch rates throughout the study period. Changes in catch rate (landings per fishing hour) were analysed taking account of the variation caused by gear type, engine power, season, area and year. We used a generalised additive mixed effect model ${ }^{1}$ (gamm) of the ' $\mathrm{mgcv}^{\prime \prime}$ library in R (Wood, 2016):

$$
\begin{gathered}
\ln \left(C P U E_{i i}\right)=\beta_{0}+\beta_{1} G_{i i}+\beta_{2} A_{i i}+\beta_{3} E_{i i}+s\left(T_{i j} ; A_{i j}\right)+\varepsilon_{i i} \\
\text { Vessel }_{i} \sim N(0, \sigma)
\end{gathered}
$$

with $\mathrm{G}_{\mathrm{ij}}=$ gear type (beam trawl or pulse trawl), $A_{i j}=$ area (area 2, 3, 3a, 4, 5, 5a), $\mathrm{E}_{\mathrm{ij}}=$ engine power, $s\left(T_{i j}: A_{i j}\right)=$ smooth term of time to allow for fitting both the seasonality as well as the changes over years for each area separately, and $\varepsilon_{\mathrm{ij}}$ is the error term with a quasipoisson distribution to allow for overdispersion. Vessel identity was included as random effect to take account of the dependency of the observations within each vessel.

\footnotetext{
${ }^{1}$ gamm(cpue.sol $\sim$ as.factor(gear) + as.factor(area $)+\ln \left(V E \_K W\right)+s($ decimal.year, by=as.factor(area), $k=20)$, random=list(VE_REF= 1), method="REML", data=dat2, family="quasipoisson")
} 
The southern North Sea was subdivided in 6 areas representing the western and eastern parts between $52^{\circ}$ and $53^{\circ} \mathrm{N}$ (Figure 1 ): area 2 = rectangles $33 \mathrm{~F} 2+34 \mathrm{~F} 2$; area 3 = rectangles $33 \mathrm{~F} 3+34 \mathrm{~F} 3$ (outside $12 \mathrm{~nm}$ zone); area $3 \mathrm{a}=$ rectangles $33 \mathrm{~F} 3+34 \mathrm{~F} 3$ (inside $12 \mathrm{~nm}$ zone)) and between $51^{\circ} \mathrm{N}$ and $52^{\circ} \mathrm{N}$ : area $4=31 \mathrm{~F} 1+32 \mathrm{~F} 1$; area $5=$ rectangles $31 \mathrm{~F} 2+32 \mathrm{~F} 2+31 \mathrm{~F} 3+32 \mathrm{~F} 3$ (outside $12 \mathrm{~nm}$ zone); area $5 \mathrm{a}=$ rectangles $31 \mathrm{~F} 2+32 \mathrm{~F} 2+31 \mathrm{~F} 3+32 \mathrm{~F} 3$ (inside $12 \mathrm{~nm}$ zone). We assumed landings and effort of vessels $<=221 \mathrm{~kW}$ in area 3 and 5 took place within the 12 zone and these were assigned to area $3 a$ and 5 a accordingly.

In some instance, the gamm model gave conversion problems, likely caused by the large number of zero observations for some of the vessels. To obtain an estimate of the changes in catch rate during the study period, the above model was simplified by omitting the random vessel effect. For the species for which the random effect model converged, the simplified model yielded similar estimates of the changes in catch rate. The main difference between the two model approaches was the wider confidence intervals around the estimated catch rate when including a random vessel effect.

\subsubsection{VMS}

Trawling intensity (swept area ratio) was estimated by $1 \times 1$ minute latitude and longitude of the beam trawlers and the pulse trawlers interpolating trawl tracks according (Hintzen et al., 2010).

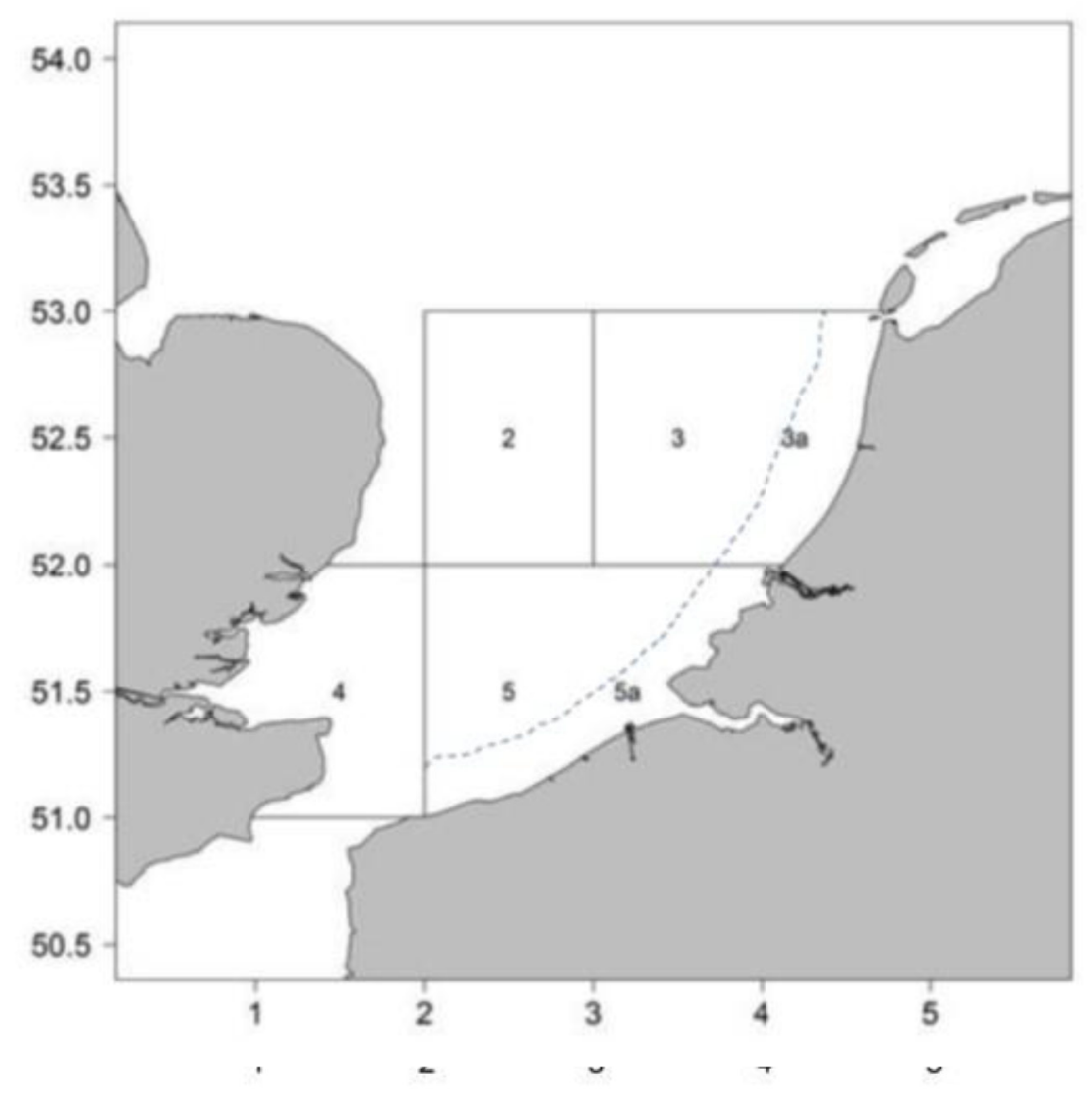

Figure 1. Map with the areas distinguished in this study to analyse the trends in catch rate (CPUE). 


\section{$3.1 \quad$ Testimonies}

The testimonies refer to commercial fishers operating in the coastal waters of the southern North Sea, in particular off the Belgium coast, deploying a variety of fishing gears (Table 1). In total testimonies of 11 small scale fishers were available fishing for sole, seabass, cod or pollack

Table 1. Fishing method, number of testimonies and fish species with declining catch.

\begin{tabular}{lccccc} 
& Number & \multicolumn{5}{c}{ Species } \\
\cline { 3 - 6 } & & Sole & Seabass & Cod & Pollack \\
\hline Handline & 5 & $(\mathrm{x})$ & $\mathrm{x}$ & $\mathrm{x}$ & \\
Charler & 3 & & $\mathrm{x}$ & $\mathrm{x}$ & $\mathrm{x}$ \\
Trammel & 2 & $\mathrm{x}$ & & & \\
Shrimp trawl & 1 & $\mathrm{x}$ & & & \\
\hline
\end{tabular}

\subsection{Effort and landings}

The reported fishing effort of small scale fishers in the southern North Sea (between $51-53^{\circ} \mathrm{N}$ ) declined during the study period. Coinciding with the drop in effort, the reported landings of sole, cod and seabass decreased as well (Table 2). Gillnet effort dropped from a level between 2400 and 3200 hours in 2009-2012 to less than 580 hours in 2013 and to zero in 2014 and following years. Reported handline effort already ceased in 2012 . The landings by beam trawl vessels ( $<=221 \mathrm{~kW}$ ) do not show a decreasing trend for sole, but for cod and seabass the landings decreased substantially.

Table 2. Annual landings ( $1000 \mathrm{~kg}$ ) of cod, seabass and sole reported by fishing method by Dutch vessels $(<=221 \mathrm{~kW})$ in the southern North Sea. Fishing methods are gillnets (GN, GNS, GTR), hand lines (LHM, LHH) and beam trawl (TBB, Pulse trawl).

small vessels $<=221 \mathrm{~kW}$

Year

Gillnet

Handlines

$\operatorname{cod}$

seabass

cod

seabass

2009

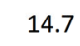

2010

9.1

sole

2011

12.1

2012

2013

2014

2015

2016

2017

0.0

1.7

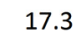

8.7

$$
\begin{aligned}
& 1.7 \\
& 0.3 \\
& 1.4 \\
& 1.3 \\
& 0.0 \\
& 0.0 \\
& 0.0 \\
& 0.0 \\
& 0.0
\end{aligned}
$$$$
12.1
$$
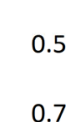

0.7

0.0

0.0

0.0

0.0

0.0

0.0

0.0

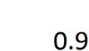

$$
0.4
$$$$
0.0
$$$$
0.0
$$$$
0.0
$$$$
0.0
$$$$
0.0
$$$$
0.0
$$$$
0.0
$$

0.0

0.0
$1 \mathrm{~kW}$ 


\subsection{Effort and landings today's pulse license holders}

In the analysis we focussed on the fleet of vessels that have switched to pulse fishing since 2009 (today's pulse license holders). Following the incremental deployment of pulse licenses, pulse fishing effort increased since 2009, while the fishing effort of traditional beam trawls targeting sole

(TBB_SOL) decreased (Figure 2). During the transition period the total effort of large vessels remained constant (all), but the percentage of effort targeting sole (SOL) decreased from $95 \%$ in 2009 to $87 \%$ in 2017, while the percentage effort targeting plaice increased. The increase in the percentage effort targeting plaice is due to some of the pulse vessels that switched back to the tickler chain beam trawl to utilise their plaice quota during part of the year. Total fishing effort of the Euro cutter license holders showed a slight increase until 2013 and then decreased to the level at the start of the study period. The proportion of effort allocated in the sole fishery was around $70 \%$ without a trend and is not affected by the introduction of the pulse trawl.

The fleet of today's pulse license holders contributed to $75 \%$ of the Dutch sole landings in 2009 and their contribution increased to about $95 \%$ after the transition to pulse fishing (Figure 3). After the transition to pulse trawling, these vessels were using the pulse trawl to target sole (PUL_SOL) with a codend mesh of $80 \mathrm{~mm}$, but also deployed other gears during part of the year. Large vessels ( $>221$ $\mathrm{kW}$ ) used conventional beam trawls with a mesh size of $>100 \mathrm{~mm}$ during part of the year to target plaice (TBB_PLE), while small vessels ( $<=221 \mathrm{~kW}$ ) used conventional shrimp beam trawls with bobbins to target shrimps (TBB_CRG) or used otter (twin) trawls to target other demersal fish or Nephrops (OTHER).
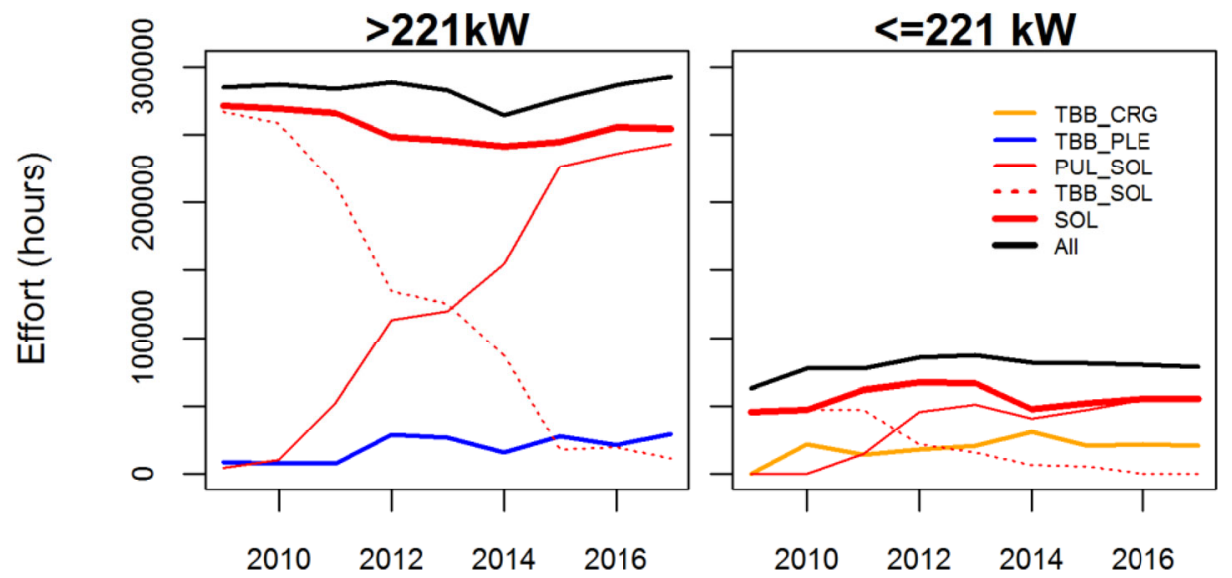

Year

Figure 2. Effort by metier of today's pulse license holders of large (left) and small vessels (right). PUL_SOL = pulse trawl fishery targeting sole ( $80 \mathrm{~mm}$ mesh size); TBB_SOL = beam trawl fishery with tickler chains targeting sole $(80 \mathrm{~mm}$ mesh size); TBB_PLE = beam trawl fishery targeting plaice (mesh size $>=100 \mathrm{~mm})$; TBB_CRG = beam trawl fishery for shrimps. SOL represents the total effort in the sole fishery (TBB_SOL + PUL_SOL). All represents the total fishing effort of the todays pulse license holders. 


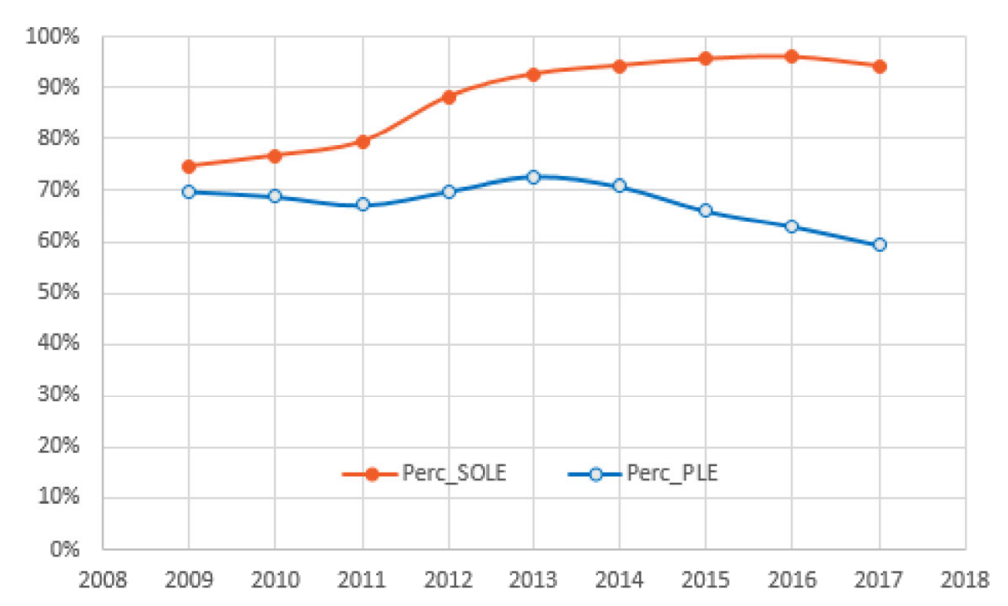

Figure 3. Contribution of the fleet of today's pulse license holders to the total landings of sole and plaice by Dutch vessels. These vessels used the traditional beam trawl before they switched to pulse trawling.

\subsection{Changes in effort and landings in the southern North Sea}

The spatial distribution of the pulse license holders targeting sole $(80 \mathrm{~mm}$ mesh size) shows a change towards fishing grounds in the southern North Sea south of $53^{\circ} 30^{\prime} \mathrm{N}$ (Figure 4). The maps show the average distribution patterns over the period 2009-2017. Hot spots of pulse trawling are apparent on the Norfolk Sandbanks and off the Thames estuary. Absolute fishing effort has decreased over large parts of the fishing area in the German Bight and remained relatively stable in the other areas. In the southern North Sea, both sole fishing effort and sole landings have increased during the transition from the traditional beam trawl to the pulse trawl, while the effort and landings in the area north of $53^{\circ} \mathrm{N}$ have decreased (Figure 5). The changes in the annual fishing effort and landings by rectangle are presented in appendix 1 and 2, respectively. Fishing effort increased in some of the rectangles for instance in the rectangle off the Thames Estuary (32F1) and to a lesser degree in $32 \mathrm{~F} 2$ off the Belgium coast. No increase in fishing effort was observed on the Norfolk Sandbanks (34F1, 34F2).
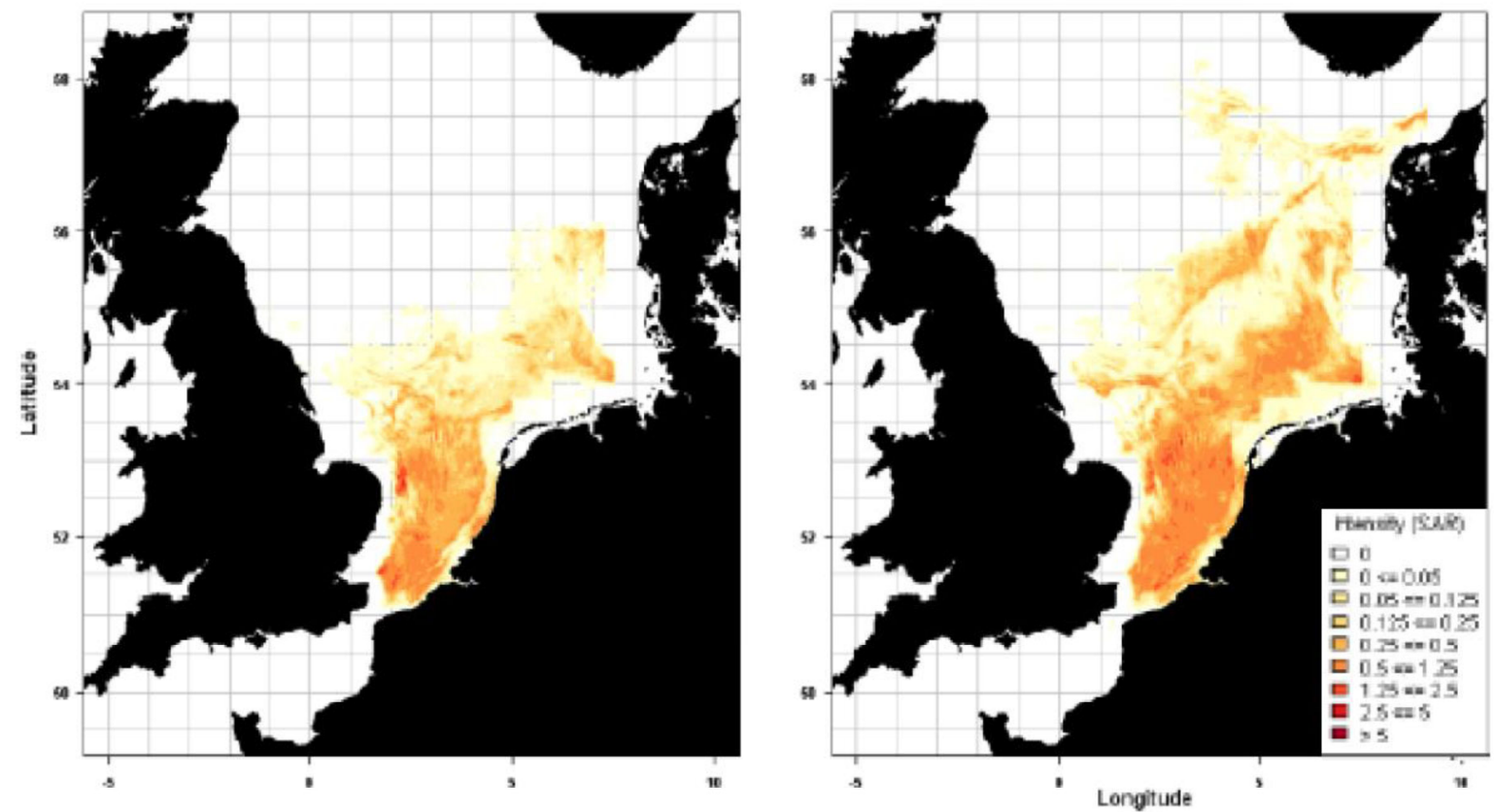

Figure 4. Average annual trawling intensity (swept area ratio of $1 \times 1$ minute grid cells) of the pulse trawls (left: PUL_SOL) and traditional beam trawl (right: TBB_SOL) in the period $2009-2017$. 

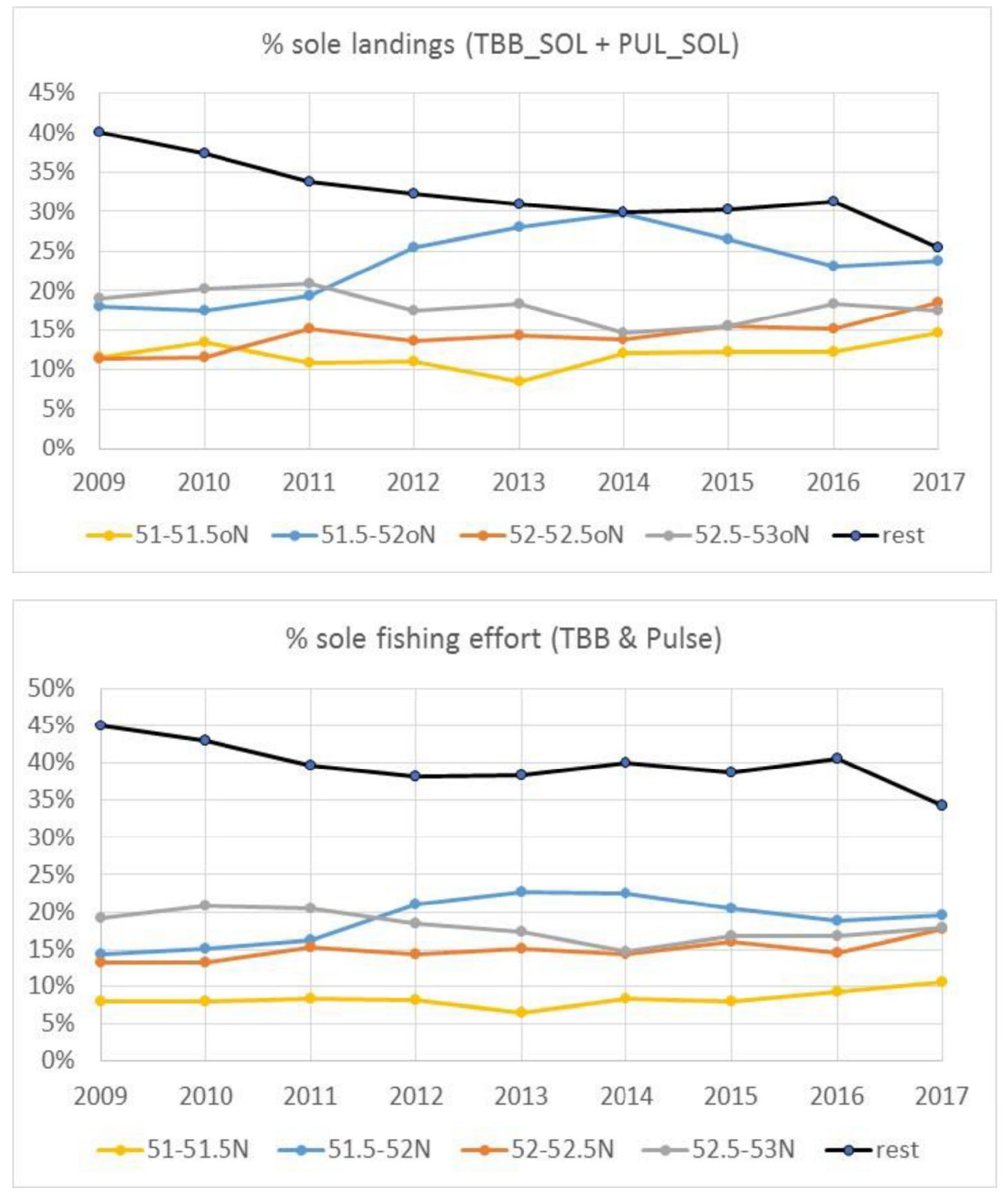

Figure 5. Sole fishing effort (bottom) and sole landings (top) of today's pulse license holders (\% of total effort or landings) allocated to different latitudinal zones in the southern North Sea by year in the period 2009 - 2017. Rest refers to the fishing area north of $53^{\circ} \mathrm{N}$.

\subsection{Changes in catch rate in the southern North Sea}

\subsubsection{Sole}

Throughout the study period the catch rate of sole of today's pulse license holders in the southern North Sea (south of $53^{\circ} \mathrm{N}$ ) was higher than in more northern areas. This is shown by the higher proportion of landings as compared to the proportion of effort. For instance, in $201775 \%$ of the sole landings were taken between $51^{\circ}$ and $53^{\circ} \mathrm{N}$ with $65 \%$ of the fishing effort, while in the area north of $53^{\circ} \mathrm{N}, 25 \%$ of the sole was taken in $35 \%$ of the fishing effort (Figure 5 ).

The estimated CPUE of sole shows a clear seasonality in area 2, 5 and 5a, but not in area 4 (Figure 6). The seasonality in area 3 is only apparent in some of the years. The seasonality in area 5 and area $5 a$ seem to have an opposite pattern which may be related to the coastal migration of sole during the spawning period which increases their catchability within the $12 \mathrm{~nm}$ zone and reduces their catchability outside the $12 \mathrm{~nm}$ zone. 
The CPUE of sole varied between years with relative low values in 2010-2012 and relative high values in 2013-2017. The analysis further suggests that in 2017, the CPUE of sole within the $12 \mathrm{~nm}$ zones decreased. No changes in CPUE are suggested in the offshore areas or in the western areas.
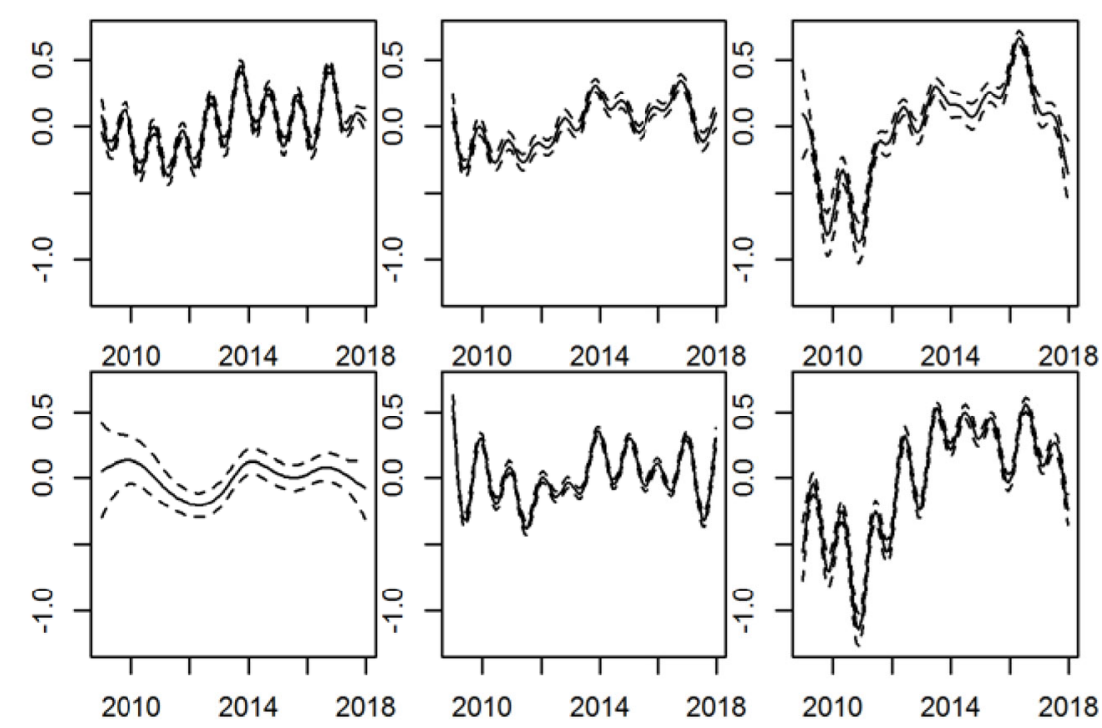

Figure 6. Sole: changes in relative CPUE and the $95 \%$ confidence interval in the southern North Sea estimated by the mixed effect gam model. Upper panels from left to right: area 2; area 3 outside 12 miles zone; area 3 inside 12 miles zone. Lower panels from left to right: area 4; area 5 outside 12 miles zone; area 5 inside 12 miles zone.

\subsubsection{Cod}

The CPUE of cod show a clear seasonality with a high value In winter and a low value in summer. The results further suggest that the amplitude of the seasonal pattern increased over time coinciding with a gradual decline in all study areas (Figure 7).

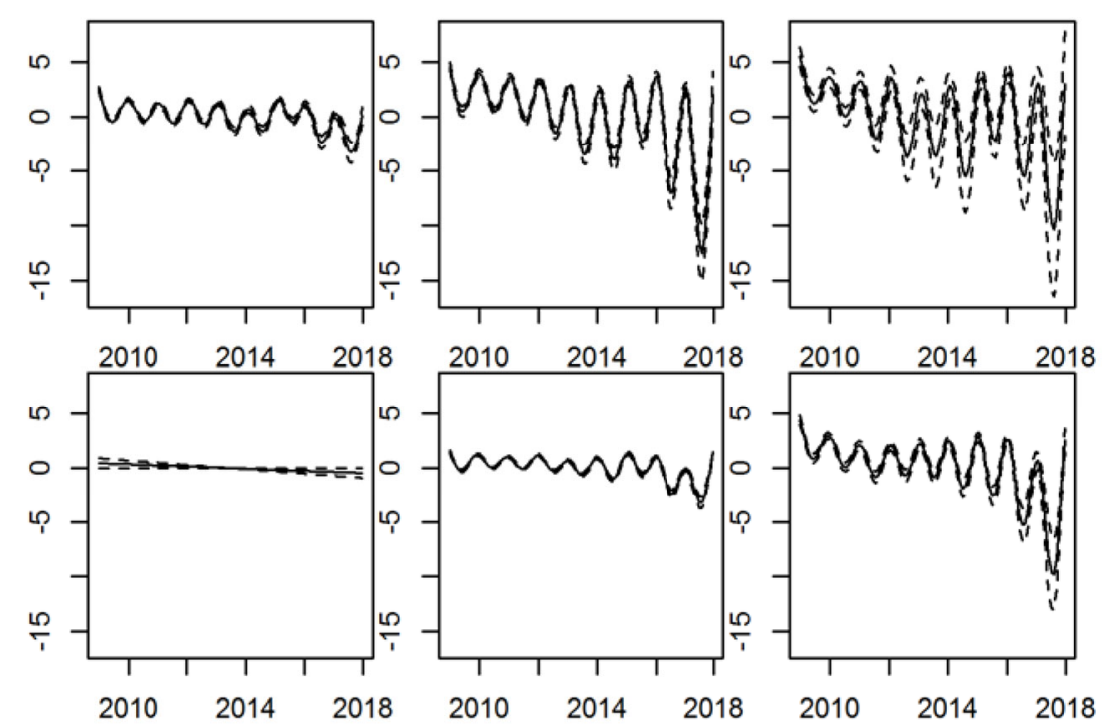

Figure 7. Cod: changes in relative CPUE and the $95 \%$ confidence interval in the southern North Sea estimated by the mixed effect gam model. Upper panels from left to right: area 2; area 3 outside 12 miles zone; area 3 inside 12 miles zone. Lower panels from left to right: area 4; area 5 outside 12 miles zone; area 5 inside 12 miles zone. 


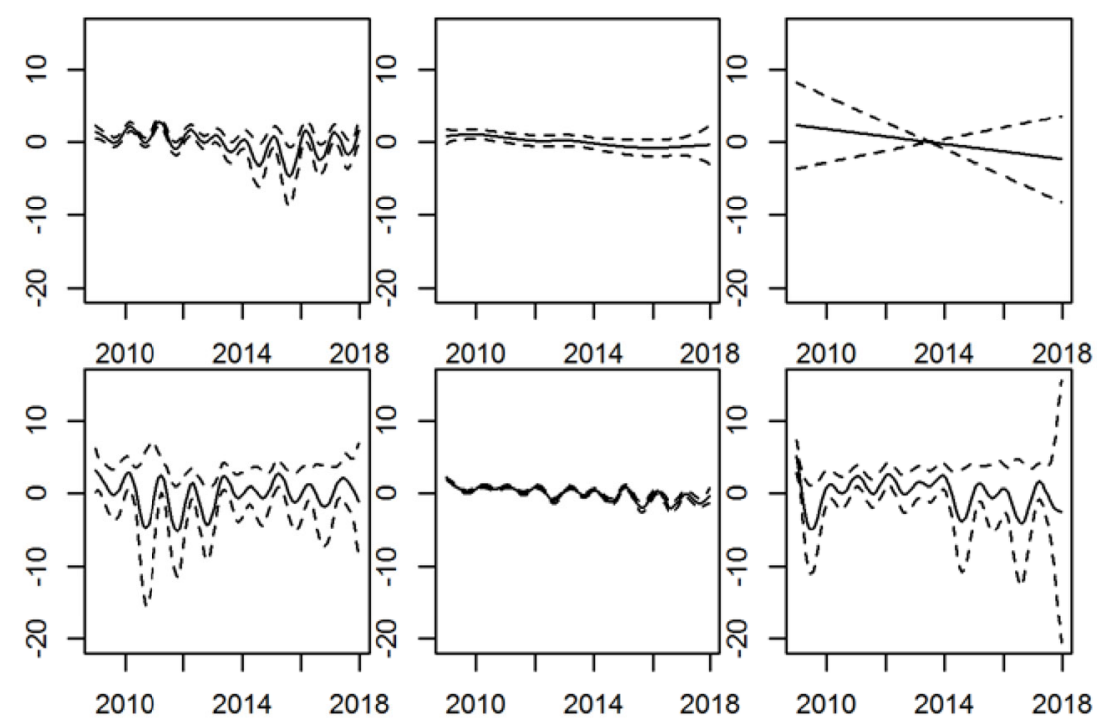

Figure 8. Seabass: changes in relative catch rate and the $95 \%$ confidence interval in the southern North Sea estimated by the simplified gam model ignoring the random effect of vessels. Upper panels from left to right: area 2; area 3 outside 12 miles zone; area 3 inside $12 \mathrm{n}$ miles $\mathrm{m}$ zone. Lower panels from left to right: area 4; area 5 outside 12 miles zone; area 5 inside 12 miles zone.

\subsubsection{Seabass}

The analysis of the CPUE of seabass failed due to convergence problems when including vessel as random effect. Simplifying the model by ignoring the random effect provided an estimate of the changes in seabass CPUE during the study period (Figure 8). The results indicate that seabass CPUE in area 3 and 5 decreased. For areas 3a, 4 and area 5a, the confidence bands are too wide to indicate a significant trend in time.

\subsubsection{All fish}

The catch rate of all fish species together show a clear seasonality with a high value in winter and a low value in summer. The results further suggests that the amplitude of the seasonal pattern has decreased over time in most areas, while the catch rate in the most recent year has reduced substantially as compared to previous years, in particular within the 12 miles zone off Belgium and the Netherlands and in the northern section of the study area (Figure 9). 

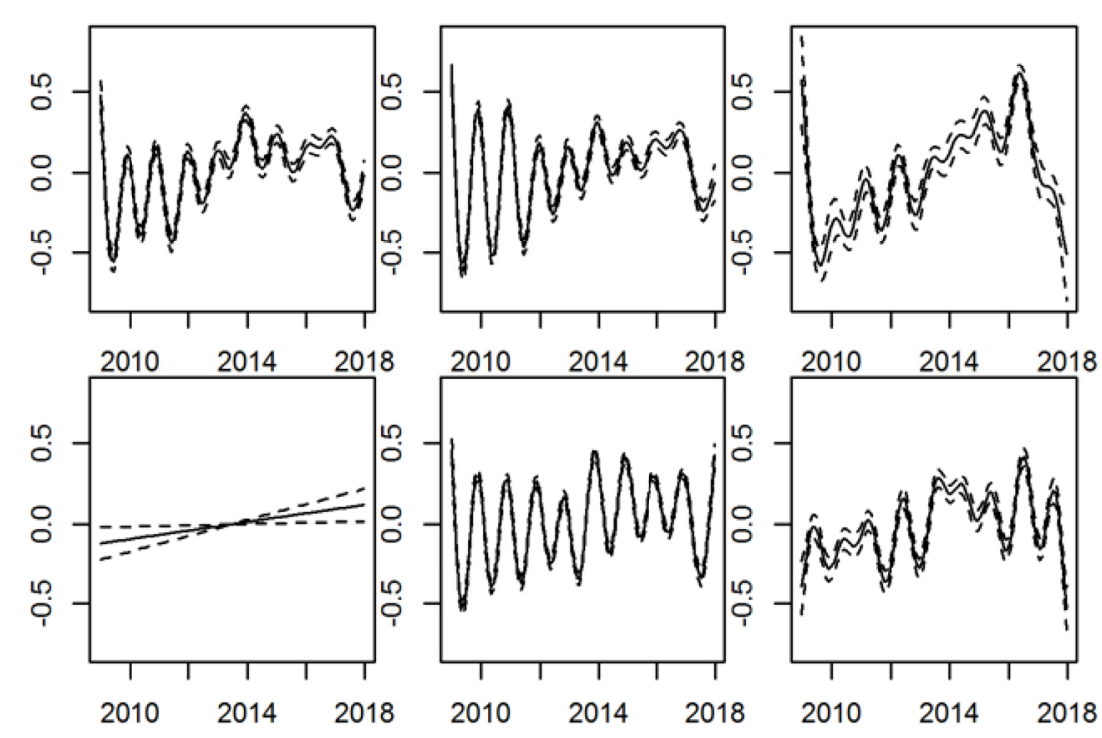

Figure 9. All fish species: changes in relative CPUE and the $95 \%$ confidence interval in the southern North Sea estimated by the mixed effect gam model. Upper panels from left to right: area 2 ; area 3 outside 12 miles zone; area 3 inside 12 miles zone. Lower panels from left to right: area 4; area 5 outside 12 miles zone; area 5 inside 12 miles zone.

\subsection{Catch efficiency of pulse trawl and beam trawl}

The statistical analysis of the CPUE also provides an estimate of the catch rate of the traditional beam trawl relative to the pulse trawl (Table 3). The analysis shows that the traditional beam trawl catches $16 \%$ (95\%CL: $14 \%-18 \%$ ) less sole as compared to the pulse trawl, while it catches $55 \%$ ( $95 \%$ CL: $50 \%-61 \%$ ) more plaice. For the total landings of fish, the catch efficiency of the traditional beam trawl is $24 \%$ ( $95 \%$ CL: $21 \%-26 \%$ ) higher. Also for cod and seabass the catch efficiency of the traditional beam trawl is higher than of the pulse trawl.

Table 3. Catch efficiency of the traditional beam trawl relative to the pulse trawl estimated with the mixed effect gam model for sole, plaice, cod and for the landings of all fish species (total fish landings).

\begin{tabular}{lccccr} 
Species & Estimate & SE & \multicolumn{3}{c}{$\begin{array}{c}\text { Catch efficiency traditional beam } \\
\text { trawl relative to pulse trawl }\end{array}$} \\
& & & lower CL & estimate & upper CL \\
Sole & -0.1706 & 0.0121 & 0.82 & 0.84 & 0.86 \\
Plaice & 0.4399 & 0.0192 & 1.50 & 1.55 & 1.61 \\
Cod & 0.8981 & 0.0489 & 2.23 & 2.45 & 2.70 \\
Seabass ${ }^{1)}$ & 1.1751 & 0.1037 & 2.64 & 3.24 & 3.97 \\
Total fish landings & 0.2112 & 0.0109 & 1.21 & 1.24 & 1.26
\end{tabular}




\section{SSB}

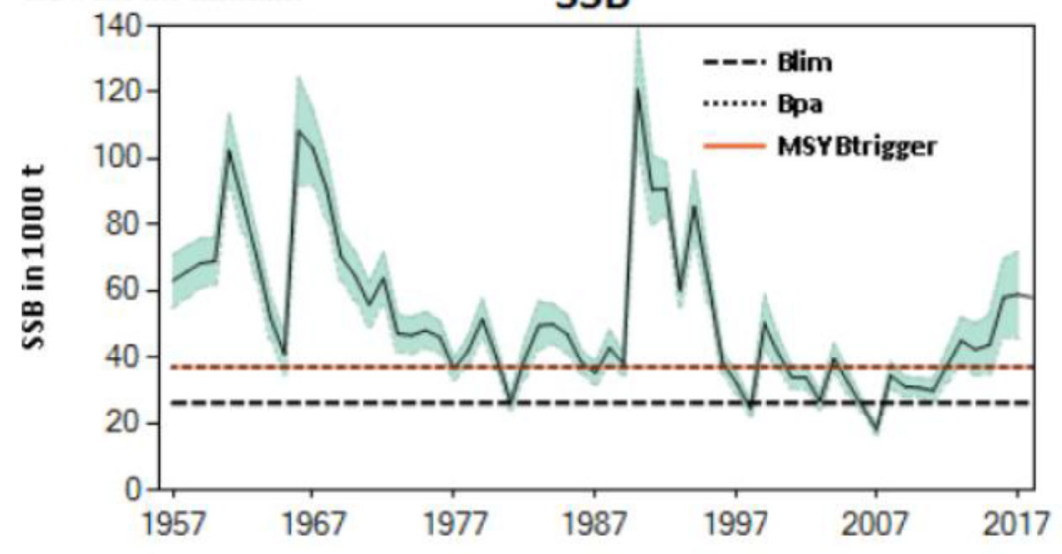

SSB

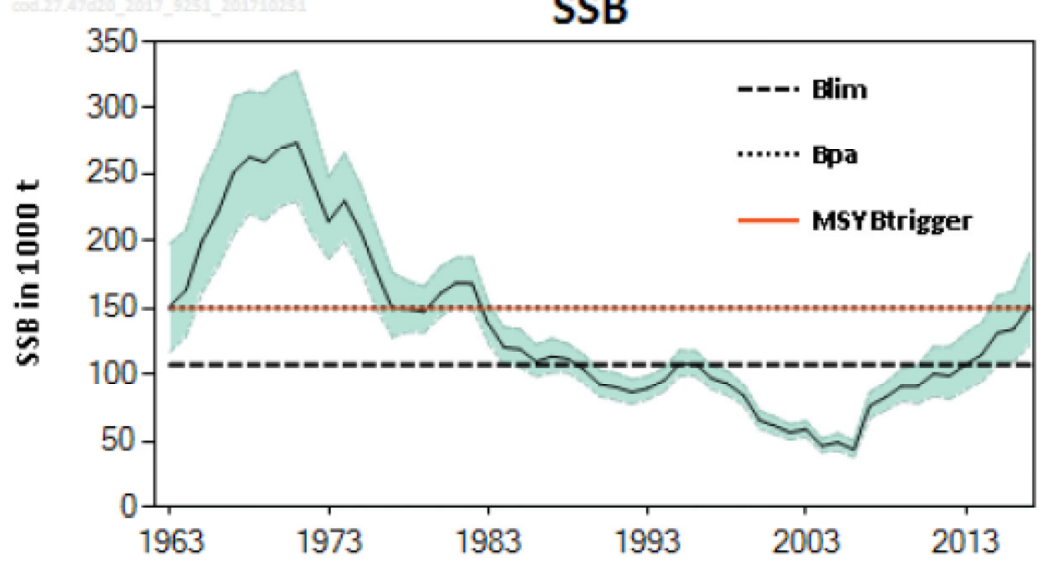

SSB

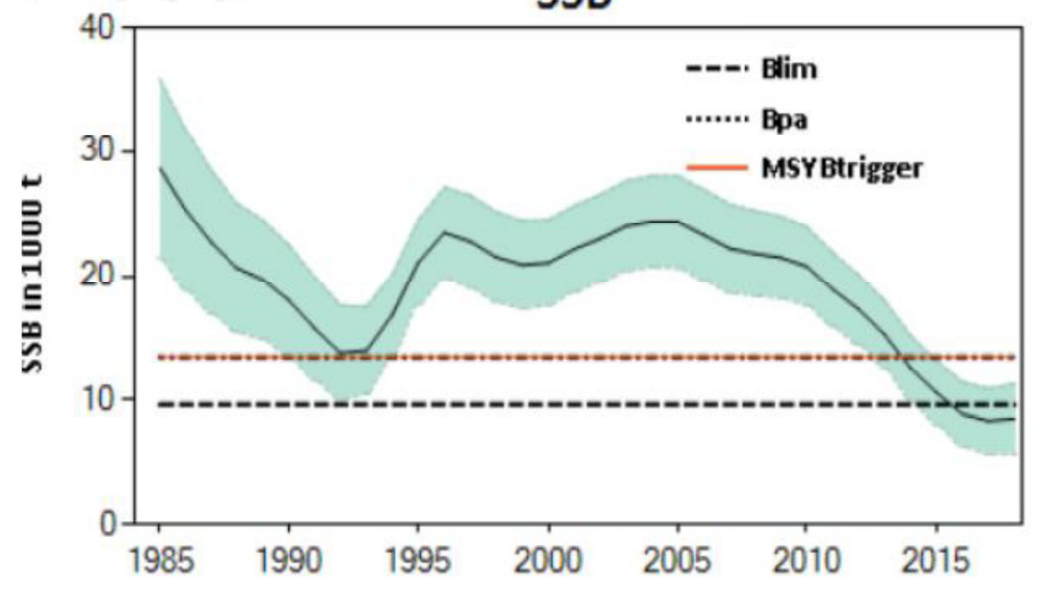

Figure 10. Trends in spawning stock biomass of North Sea sole ${ }^{2}$ (upper panel), $\operatorname{cod}^{3}$ (middle panel) and seabass ${ }^{4}$ (lower panel) estimated by ICES. The blue band shows the $95 \%$ confidence limits of the SSB estimate. Blim, Bpa and MSYBtrigger are the reference levels used by ICES to assess the sustainability of the fisheries.

\footnotetext{
${ }^{2}$ http://www.ices.dk/sites/pub/Publication\%20Reports/Advice/2018/2018/sol.27.4.pdf

${ }^{3}$ http://ices.dk/sites/pub/Publication\%20Reports/Advice/2018/2018/cod.27.47d20.pdf

${ }^{4}$ http://ices.dk/sites/pub/Publication\%20Reports/Advice/2018/2018/bss.27.4bc7ad-h.pdf
} 


\section{Discussion}

The testimonies of small scale fishers about the decline in the catch opportunities in the southern North Sea is in agreement with the reported landings of the fishing vessels deploying either gill nets or hand-lines. There are several possible causes for the observed reduction in landings of small-scale fishers of their main target species sole, cod and seabass. Below we will discuss the possible causes.

The decrease in catch opportunities of small scale fishers may due to a decrease in the biomass of the target species, or due to a decrease in the catchability, or both. The spawning stock biomass (SSB) of target species (Figure 10), as estimated by ICES, does only partly match the pattern in landings of small-scale fishers.

The decrease in catch opportunities of sole for small scale fishers does not match the trends in SSB estimated by ICES. Sole SSB increased during the study period and is estimated in 2017 to be twice the SSB in 2009. This increase in SSB is reflected in the CPUE trend of beam trawl vessels in the southern North Sea which showed relatively high values in the period 2012-2016. The sharp decline in the CPUE in 2017, however, is not reflected in the SSB. The decline may be due to two incoming year classes - 1 year olds in 2016 and 2017 - which are below average size. The reduced catch of sole of small scale fishers is therefore unlikely due to the lack of sole on the fishing grounds. It is more likely due to a reduced catchability - fish may still be around on the fishing grounds but harder to catch for gill nets and hand-lines. This reduction in catchability may be caused by an increased competition with the pulse trawl fleet. Sys et al., (2016) showed that the catch rate of Belgian beam trawlers were reduced during weekdays when they competed with Dutch pulse trawl vessels but not during the weekends when the Dutch fleet was in the harbour.

The decrease in catch opportunities of cod for small scale fishers does not match the overall trend in cod SSB which gradually increased during the study period. The increase in the cod SSB in the total North Sea is also not reflected in the beam trawl CPUE in the southern North Sea which remained stable during the winter period and decreased during summer. This indicates that the recovery of the North Sea cod stock mainly occurs in the northern parts of the North Sea. This inference is supported by the trend in cod abundance in the international bottom trawl surveys (ICES Advice 2018 cod.27.47d20.pdf). The CPUE of beam trawlers may have become biased since the transition to the pulse trawl because fishers may discard part of the catch that developed a spinal injury and associated haemorrhage (van Marlen et al., 2014; de Haan et al., 2016; ICES, 2018). This may also have affected the estimated catch efficiency of the pulse trawl for cod.

The decrease in the catch opportunities of seabass for small scale fishers is consistent with the decrease in SSB estimated by ICES and the decrease in CPUE of the beam trawl fishery in the southern North Sea. It is unlikely that the transition to pulse trawling will have contributed to the decline in seabass SSB. Beam trawls only contribute a small proportion of the total international catches of seabass (about 1\%) and the catch efficiency of the pulse trawls is substantially lower than of the traditional beam trawl. The catch opportunities may be influenced by the response of seabass to the electric fields of pulse trawls. It has been suggested that seabass may avoid areas where pulse trawlers are working but no information on this potential process is available.

Pulse trawls are more efficient in catching sole, but less efficient in catching plaice, cod or other fish in general. The estimated increase in efficiency for sole for the pulse trawl in this report (representative for all beam trawl vessels irrespective of their engine power) is slightly less than the estimate of Poos which applied to large beam trawlers only (ICES, 2018).

The increase in fishing effort in combination with the improved catch efficiency of the pulse vessels in the southern North Sea resulted in an increase in fishing pressure on the sole stock in the southern North Sea. The consequences of this shift in distribution of fishing pressure will depend on the 
structure of local sole stocks within the North Sea and the movement of sole. Tagging experiments and the analysis of the micro-chemistry of otoliths have revealed that sole juveniles don't migrate between different nursery grounds and will likely recruit to the local spawning stock (Cuveliers, 2011). Hence, an increase in fishing pressure in coastal waters may reduce the recruitment to the local sole stock. How the increase in fishing pressure on the adult sole affects the dynamics of the local stock is unknown.

Changes in fishing opportunities in the coastal waters may also be influenced by changes in ecosystem productivity or changes in environmental conditions. In the $1980 \mathrm{~s}$, high fish biomass levels were recorded in the waters along the Dutch coast in the annual fish survey, which coincided with the peak nutrients (Tulp et al., 2008; Philippart et al., 2007). Since then nutrients and fish biomass have decreased. Survey data showed that in the recent decade, fish biomass of large fish $(31-50 \mathrm{~cm}) \mathrm{has}$ decreased (Tulp et al., 2017). In addition to the decline in nutrients, the change may also be influenced by the increase in temperature in coastal waters. Poleward shifts in distribution have been reported in relation to temperature (Perry et al., 2005), as well as to deeper (cooler) waters (Dulvy et al., 2008; Perry et al., 2005; van Hal et al., 2016; van Keeken et al., 2007). 


\section{$5 \quad$ References}

Anon, 2017. Getuigenissen over de terugvallende visvangsten in de zuidelijke Noordzee. Rapport van een bijeenkomst georganiseerd door LIFSN op 1 September 2017, Nieuwpoort, België. Pp 7.

Cuveliers, E. 2011. Connectivity and genetic stability in sole (Solea solea). PhD-thesis, Faculty of Science, Department of Biology, Katholieke Universiteit Leuven, Leuven. p. 256.

de Haan, D., Fosseidengen, J. E., Fjelldal, P. G., Burggraaf, D., and Rijnsdorp, A. D. 2016. Pulse trawl fishing: characteristics of the electrical stimulation and the effect on behaviour and injuries of Atlantic cod (Gadus morhua). ICES Journal of Marine Science, 73: 1557-1569.

Dulvy, N. K., Rogers, S. I., Jennings, S., Stelzenmüller, V., Dye, S. R., and Skjoldal, H. R. 2008. Climate change and deepening of the North Sea fish assemblage: a biotic indicator of warming seas. Journal of Applied Ecology, 45: 1029-1039.

Hintzen, N. T., Piet, G. J., and Brunel, T. 2010. Improved estimation of trawling tracks using cubic Hermite spline interpolation of position registration data. Fisheries Research, 101: 108-115.

ICES. 2018. Report of the Working Group on Electric Trawling (WGELECTRA). 17-19 April 2018. IJmuiden, The Netherlands. ICES CM 2018/EOSG:10.

Perry, A. L., Low, P. J., Ellis, J. R., and Reynolds, J. D. 2005. Climate change and distribution shifts in marine fishes. Science, 308: 1912-1915

Philippart, C. J. M., Beukema, J. J., Cadee, G. C., Dekker, R., Goedhart, P. W., van Iperen, J. M., Leopold, M. F., et al. 2007. Impacts of nutrient reduction on coastal communities. Ecosystems, 10: 95-118.

Sys, K., Poos, J. J., Van Meensel, J., Polet, H., and Buysse, J. 2016. Competitive interactions between two fishing fleets in the North Sea. ICES Journal of Marine Science: 73: 1485-1493

Steijns, N. 2018. Bijeenkomst passieve visserij rond vragen over pulsvisserij. Notulen bijeenkomst 16 maart 2018, Zeehaven IJmuiden. Wageningen University \& Research. 1808391.NSt.mb. 8 pp.

Tulp, I., Bolle, L. J., and Rijnsdorp, A. D. 2008. Signals from the shallows: In search of common patterns in long-term trends in Dutch estuarine and coastal fish. Journal of Sea Research, 60: 54-73.

Tulp, I., van der Veer, H. W., Walker, P., van Walraven, L., and Bolle, L. J. 2017. Can guild- or site-specific contrasts in trends or phenology explain the changed role of the Dutch Wadden Sea for fish? Journal of Sea Research, 127: 150-163.

Turenhout, M.N.J., B.W. Zaalmink, W.J. Strietman, K.G. Hamon. 2016. Pulse fisheries in the Netherlands; Economic and spatial impact study. Wageningen Economic Research, Report 2016-104. 32 pp

van Hal, R., van Kooten T. and Rijnsdorp, A. D. 2016. Temperature induced changes in size dependent distributions of two boreal and three Lusitanian flatfish species: a comparative study. Journal of Sea Research, 107: 14-22.

van Keeken, O. A., van Hoppe, M., Grift, R. E., and Rijnsdorp, A. D. 2007. Changes in the spatial distribution of North Sea plaice (Pleuronectes platessa) and implications for fisheries management. Journal of Sea Research, 57: 187-197. 
van Marlen, B., Wiegerinck, J. A. M., van Os-Koomen, E., and van Barneveld, E. 2014. Catch comparison of flatfish pulse trawls and a tickler chain beam trawl. Fisheries Research, 151: 57-69

Wood, S.N. 2017. Generalized Additive Models: An Introduction with R (2nd edition). Chapman and Hall/CRC. 


\section{Quality Assurance}

Wageningen Marine Research utilises an ISO 9001:2008 certified quality management system (certificate number: 187378-2015-AQ-NLD-RvA). This certificate is valid until 15 September 2018. The organisation has been certified since 27 February 2001. The certification was issued by DNV Certification B.V. 


\section{Justification}

Report C051/18

Project Number: 4318200032

The scientific quality of this report has been peer reviewed by a colleague scientist and a member of the Management Team of Wageningen Marine Research

Approved: $\quad$ Dr. Ingrid Tulp

Senior Researcher

Signature: Jegeed 8 wip

Date: 14-08-2018

Approved: $\quad$ Dr. ir. T.P. Bult

Director

Signature:

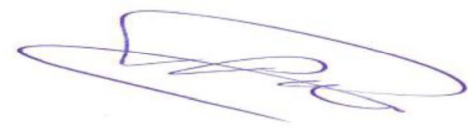

Date:

14-08-2018 


\section{$7 \quad$ Appendices}

Appendix 1. Fishing effort (hours) of the pulse license holders fishing with the traditional beam trawl (TBB_SOL) or with the pulse trawl (PUL_SOL) by ICES rectangle in the southern North Sea. The total effort gives the annual effort in the North Sea.

\begin{tabular}{llllllllll}
\multicolumn{2}{l}{ Large beam trawlers (TBB_SOL + PUL_SOL) } & & & & & \\
& 2009 & 2010 & 2011 & 2012 & 2013 & 2014 & 2015 & 2016 & 2017 \\
Total effort & 270999 & 269032 & 265607 & 248550 & 245723 & 241418 & 244867 & 255760 & 254707 \\
$31 \mathrm{~F} 1$ & 95 & 458 & 196 & 932 & 457 & 187 & 460 & 733 & 720 \\
$31 \mathrm{~F} 2$ & 13544 & 14291 & 12779 & 13367 & 11822 & 13350 & 12871 & 16099 & 14461 \\
$31 \mathrm{~F} 3$ & 979 & 805 & 0 & 0 & 98 & 39 & 0 & 32 & 100 \\
$32 \mathrm{~F} 1$ & 229 & 0 & 2675 & 5768 & 4939 & 4011 & 4111 & 3761 & 2950 \\
$32 \mathrm{~F} 2$ & 24518 & 23544 & 28588 & 34754 & 28803 & 32289 & 31671 & 28394 & 30479 \\
$32 \mathrm{~F} 3$ & 7821 & 6450 & 4535 & 4765 & 8350 & 8397 & 4159 & 6939 & 6512 \\
$32 \mathrm{~F} 4$ & 0 & 0 & 84 & 0 & 0 & 0 & 0 & 91 & 18 \\
$33 \mathrm{~F} 1$ & 0 & 0 & 103 & 0 & 0 & 0 & 103 & 0 & 100 \\
$33 \mathrm{~F} 2$ & 13392 & 11919 & 11834 & 11580 & 11227 & 8034 & 11294 & 12716 & 18832 \\
$33 \mathrm{~F} 3$ & 17595 & 18192 & 19424 & 15608 & 16992 & 18535 & 20201 & 15483 & 20560 \\
$33 \mathrm{~F} 4$ & 852 & 2025 & 1182 & 914 & 985 & 1305 & 2329 & 1941 & 2085 \\
$34 \mathrm{~F} 1$ & 0 & 0 & 97 & 162 & 104 & 0 & 99 & 0 & 0 \\
$34 \mathrm{~F} 2$ & 29578 & 27758 & 29856 & 23795 & 27513 & 25031 & 23684 & 23698 & 28124 \\
$34 \mathrm{~F} 3$ & 17161 & 19400 & 16198 & 17497 & 18126 & 11618 & 15735 & 17512 & 19051 \\
$34 \mathrm{~F} 4$ & 7317 & 10268 & 9243 & 4869 & 3612 & 4317 & 5188 & 4392 & 5120
\end{tabular}

Small beam trawlers (TBB_SOL + PUL_SOL)

$\begin{array}{llllllllll}\text { Total effort } & 45524 & 47394 & 61962 & 67165 & 66422 & 47522 & 52231 & 55198 & 55482 \\ 31 \mathrm{~F} 1 & 174 & 426 & 462 & 279 & 187 & 307 & 0 & 89 & 41 \\ 31 \mathrm{~F} 2 & 9571 & 7871 & 11776 & 10511 & 6503 & 9344 & 9078 & 10287 & 14404 \\ 31 \mathrm{~F} 3 & 1051 & 1007 & 1994 & 809 & 1334 & 585 & 1013 & 1259 & 2714 \\ 31 \mathrm{~F} 4 & 0 & 0 & 74 & 90 & 0 & 0 & 0 & 0 & 154 \\ 32 \mathrm{~F} 1 & 0 & 186 & 388 & 93 & 497 & 195 & 16 & 88 & 0 \\ 32 \mathrm{~F} 2 & 3995 & 6839 & 7314 & 10846 & 16224 & 10736 & 9605 & 11514 & 7307 \\ 32 \mathrm{~F} 3 & 8874 & 10466 & 9261 & 9489 & 10788 & 9123 & 9703 & 7875 & 11545 \\ 32 \mathrm{~F} 4 & 95 & 224 & 194 & 310 & 1309 & 243 & 1730 & 104 & 1621 \\ 33 \mathrm{~F} 1 & 0 & 0 & 153 & 0 & 0 & 0 & 0 & 0 & 0 \\ 33 \mathrm{~F} 2 & 398 & 558 & 2052 & 922 & 370 & 151 & 0 & 285 & 2037 \\ 33 \mathrm{F3} & 1540 & 2326 & 1875 & 2516 & 3949 & 4364 & 3717 & 978 & 2419 \\ 33 \mathrm{~F} 4 & 8365 & 7193 & 13297 & 13647 & 13377 & 9297 & 9978 & 13726 & 8787 \\ 34 \mathrm{~F} 2 & 452 & 0 & 339 & 289 & 210 & 0 & 0 & 0 & 78 \\ 34 \mathrm{F3} & 1561 & 841 & 2054 & 2555 & 762 & 171 & 1304 & 1567 & 591 \\ 34 \mathrm{~F} 4 & 4901 & 7525 & 9625 & 9021 & 3752 & 1514 & 4188 & 5327 & 2781\end{array}$


All vessels (TBB_SOL + PUL_SOL)

$\begin{array}{llllllllll}\text { Total effort } & 316523 & 316426 & 327569 & 315715 & 312144 & 288940 & 297098 & 310958 & 310189 \\ 31 \mathrm{~F} 1 & 269 & 883 & 658 & 1211 & 643 & 494 & 460 & 822 & 761 \\ 31 \mathrm{~F} 2 & 23115 & 22162 & 24555 & 23879 & 18325 & 22694 & 21950 & 26387 & 28865 \\ 31 \mathrm{~F} 3 & 2030 & 1812 & 1994 & 809 & 1432 & 624 & 1013 & 1291 & 2814 \\ 31 \mathrm{~F} 4 & 229 & 0 & 2749 & 5858 & 4939 & 4011 & 4111 & 3761 & 3104 \\ 32 \mathrm{~F} 1 & 24518 & 23730 & 28976 & 34847 & 29301 & 32484 & 31688 & 28482 & 30479 \\ 32 \mathrm{~F} 2 & 11816 & 13289 & 11849 & 15611 & 24574 & 19133 & 13764 & 18453 & 13819 \\ 32 \mathrm{~F} 3 & 8874 & 10466 & 9345 & 9489 & 10788 & 9123 & 9703 & 7965 & 11564 \\ 32 \mathrm{~F} 4 & 95 & 224 & 297 & 310 & 1309 & 243 & 1833 & 104 & 1721 \\ 33 \mathrm{~F} 1 & 13392 & 11919 & 11987 & 11580 & 11227 & 8034 & 11294 & 12716 & 18832 \\ 33 \mathrm{~F} 2 & 17993 & 18750 & 21476 & 16529 & 17362 & 18687 & 20201 & 15767 & 22597 \\ 33 \mathrm{~F} 3 & 2392 & 4352 & 3057 & 3431 & 4934 & 5670 & 6047 & 2919 & 4505 \\ 33 \mathrm{~F} 4 & 8365 & 7193 & 13394 & 13809 & 13482 & 9297 & 10078 & 13726 & 8787 \\ 34 \mathrm{~F} 2 & 30030 & 27758 & 30195 & 24084 & 27723 & 25031 & 23684 & 23698 & 28202 \\ 34 \mathrm{~F} 3 & 18722 & 20241 & 18253 & 20052 & 18888 & 11788 & 17039 & 19079 & 19642 \\ 34 \mathrm{~F} 4 & 12218 & 17793 & 18868 & 13890 & 7364 & 5831 & 9377 & 9719 & 7901\end{array}$


Appendix 2. Landings of sole $\left(10^{3} \mathrm{~kg}\right)$ of the Dutch pulse license holders fishing with the traditional beam trawl (TBB_SOL) or with the pulse trawl (PUL_SOL) by ICES rectangles in the southern North Sea

\begin{tabular}{|c|c|c|c|c|c|c|c|c|c|}
\hline & 2009 & 2010 & 2011 & 2012 & 2013 & 2014 & 2015 & 2016 & 2017 \\
\hline \multicolumn{10}{|c|}{ TBB_SOL + PUL_SOL } \\
\hline $31 \mathrm{~F} 1$ & 5 & 30 & 15 & 32 & 20 & 14 & 23 & 30 & 32 \\
\hline $31 \mathrm{~F} 2$ & 739 & 769 & 602 & 765 & 671 & 949 & 959 & 1104 & 1097 \\
\hline $31 \mathrm{~F} 3$ & 19 & 20 & 35 & 20 & 42 & 16 & 25 & 41 & 66 \\
\hline $32 \mathrm{~F} 1$ & 7 & 3 & 91 & 167 & 185 & 163 & 145 & 168 & 100 \\
\hline $32 \mathrm{~F} 2$ & 916 & 825 & 860 & 1421 & 1676 & 1748 & 1613 & 1534 & 1363 \\
\hline $32 \mathrm{~F} 3$ & 272 & 244 & 202 & 292 & 513 & 501 & 367 & 497 & 451 \\
\hline $32 \mathrm{~F} 4$ & 0 & 2 & 3 & 4 & 32 & 8 & 50 & 6 & 32 \\
\hline $33 \mathrm{~F} 1$ & 0 & 0 & 4 & 0 & 0 & 0 & 3 & 0 & 4 \\
\hline $33 \mathrm{H} 2$ & 311 & 258 & 312 & 321 & 400 & 261 & 369 & 479 & 681 \\
\hline $33 \mathrm{~F} 3$ & 338 & 351 & 369 & 388 & 501 & 638 & 640 & 493 & 601 \\
\hline $33 \mathrm{~F} 4$ & 102 & 102 & 211 & 298 & 326 & 224 & 261 & 475 & 222 \\
\hline $34 \mathrm{~F} 1$ & 0 & 0 & 1 & 5 & 3 & 0 & 3 & 0 & 0 \\
\hline $34 \mathrm{~F} 2$ & 746 & 606 & 656 & 637 & 933 & 793 & 705 & 871 & 805 \\
\hline $34 \mathrm{~F} 3$ & 324 & 387 & 318 & 386 & 468 & 265 & 368 & 576 & 456 \\
\hline $34 \mathrm{~F} 4$ & 188 & 249 & 268 & 267 & 176 & 127 & 201 & 302 & 171 \\
\hline \multicolumn{10}{|c|}{ TBB_SOL } \\
\hline $31 \mathrm{~F} 1$ & 5 & 30 & 10 & 4 & 12 & 0 & 0 & 0 & 4 \\
\hline $31 \mathrm{~F} 2$ & 739 & 769 & 588 & 369 & 237 & 132 & 0 & 0 & 6 \\
\hline $31 \mathrm{~F} 3$ & 19 & 20 & 15 & 14 & 3 & 2 & 0 & 0 & 0 \\
\hline $32 \mathrm{~F} 1$ & 7 & 3 & 0 & 0 & 2 & 0 & 0 & 0 & 0 \\
\hline $32 \mathrm{~F} 2$ & 916 & 825 & 818 & 524 & 327 & 146 & 7 & 0 & 4 \\
\hline $32 \mathrm{~F} 3$ & 272 & 244 & 142 & 111 & 225 & 205 & 28 & 2 & 0 \\
\hline $32 \mathrm{~F} 4$ & 0 & 2 & 1 & 1 & 0 & 0 & 0 & 0 & 0 \\
\hline $33 \mathrm{~F} 1$ & 0 & 0 & 3 & 0 & 0 & 0 & 0 & 0 & 0 \\
\hline $33 \mathrm{~F} 2$ & 311 & 258 & 268 & 154 & 133 & 15 & 7 & 1 & 0 \\
\hline $33 \mathrm{~F} 3$ & 336 & 351 & 314 & 302 & 352 & 360 & 8 & 12 & 6 \\
\hline $33 \mathrm{~F} 4$ & 102 & 102 & 102 & 33 & 79 & 30 & 19 & 3 & 7 \\
\hline $34 \mathrm{~F} 1$ & 0 & 0 & 1 & 0 & 0 & 0 & 0 & 0 & 0 \\
\hline $34 \mathrm{~F} 2$ & 690 & 440 & 221 & 135 & 251 & 92 & 56 & 1 & 8 \\
\hline $34 \mathrm{~F} 3$ & 323 & 346 & 240 & 204 & 272 & 111 & 8 & 10 & 19 \\
\hline $34 \mathrm{~F} 4$ & 181 & 249 & 215 & 149 & 111 & 43 & 15 & 17 & 12 \\
\hline
\end{tabular}

PUL_SOL

\begin{tabular}{llllllllll}
\hline & 2009 & 2010 & 2011 & 2012 & 2013 & 2014 & 2015 & 2016 & 2017 \\
\hline $31 \mathrm{~F} 1$ & 0 & 0 & 5 & 28 & 8 & 14 & 23 & 30 & 28 \\
\hline $31 \mathrm{~F} 2$ & 0 & 0 & 14 & 395 & 433 & 818 & 959 & 1104 & 1091 \\
\hline $31 \mathrm{~F} 3$ & 0 & 0 & 20 & 6 & 40 & 15 & 25 & 41 & 66 \\
\hline $32 \mathrm{~F} 1$ & 0 & 0 & 90 & 167 & 183 & 163 & 145 & 168 & 100 \\
\hline $32 \mathrm{~F} 2$ & 0 & 0 & 12 & 897 & 1319 & 1602 & 1606 & 1531 & 1360 \\
\hline $32 \mathrm{~F} 3$ & 0 & 0 & 61 & 181 & 288 & 297 & 340 & 495 & 451 \\
\hline $32 \mathrm{~F} 4$ & 0 & 0 & 2 & 3 & 32 & 8 & 50 & 6 & 32 \\
\hline
\end{tabular}




\begin{tabular}{|c|c|c|c|c|c|c|c|c|c|}
\hline 33F1 & 0 & 0 & 2 & 0 & 0 & 0 & 3 & 0 & 4 \\
\hline $33 F 2$ & 0 & 0 & 44 & 167 & 267 & 245 & 361 & 478 & 681 \\
\hline 33F3 & 2 & 0 & 56 & 86 & 149 & 278 & 633 & 481 & 595 \\
\hline $33 F 4$ & 0 & 0 & 109 & 266 & 247 & 195 & 242 & 472 & 215 \\
\hline 34F1 & 0 & 0 & 0 & 5 & 3 & 0 & 3 & 0 & 0 \\
\hline $34 \mathrm{~F} 2$ & 56 & 166 & 435 & 502 & 681 & 701 & 649 & 870 & 797 \\
\hline $34 \mathrm{~F} 3$ & 1 & 41 & 78 & 182 & 197 & 154 & 360 & 566 & 437 \\
\hline $34 \mathrm{~F} 4$ & 7 & 0 & 52 & 118 & 64 & 84 & 186 & 285 & 158 \\
\hline
\end{tabular}


Wageningen Marine Research

$\mathrm{T}+31$ (0)317 480900

E: marine-research@wur.nl www.wur.eu/marine-research

Visitors' address

- Ankerpark 271781 AG Den Helder

- Korringaweg 7,4401 NT Yerseke

- Haringkade 1, 1976 CP IJmuiden
Wageningen Marine Research is the Netherlands research institute established to provide the scientific support that is essential for developing policies and innovation in respect of the marine environment, fishery activities, aquaculture and the maritime sector.

\section{Wageningen University \& Research:}

is specialised in the domain of healthy food and living environment.

\section{The Wageningen Marine Research vision}

'To explore the potential of marine nature to improve the quality of life'

\section{The Wageningen Marine Research mission}

- To conduct research with the aim of acquiring knowledge and offering advice on the sustainable management and use of marine and coastal areas.

- Wageningen Marine Research is an independent, leading scientific research institute

Wageningen Marine Research is part of the international knowledge organisation Wageningen UR (University \& Research centre). Within Wageningen UR, nine specialised research institutes of the Stichting Wageningen Research Foundation have joined forces with Wageningen University to help answer the most important questions in the domain of healthy food and living environment. 